\title{
3D バネモデルに基づいた音楽に応じた動作の 自動生成*
}

\section{王 旗 ${ }^{\dagger} \cdot 才$ 脇 直樹}

\author{
Automatic Motion Generation Corresponding to Music \\ Based on 3D Spring Model*
}

Qi WANG ${ }^{\dagger}$, Naoki SAIWAKI ${ }^{\dagger}$ and Shogo NisHIDA ${ }^{\dagger}$

This paper proposes an approach to automatic motion generation of 3D spring model with music. Music factors are extracted from MIDI (Music Instrument Digital Interface) file. Instead of designing and calculating animation of an object directly, a sequence of motion-controllers, which can finish a set of motions affected by music factors, are automatically generated through a synthesis algorithm. A prototype system is developed to evaluate the motion generator and it is confirmed that the users are satisfied with the generated motion based on music.

\section{1.はじめに}

近年， 3 次元コンピュータグラフィックス $(\mathrm{CG})$ を用 いたアニメーションやコマーシャル,あるいは SFX 映画 などが一般化してきた.しかし，このような CG 動画を 作成する際にはモデリングやレンダリング，そしてイン バースキネマティックスといった主要な製作階段におい て，それぞれ膨大な手作業によるパラメータの設定が 必要となる. 最近のソフトウェア技術の発達と計算機パ ワーの増大によって，これらを補助する様々な手法が実 用化されつつあるが，まだまだ経験者の手作業に頼らざ るを得ない状況に変化はない。

まず，外部からの刺激に合った動きに対する研究の現 状について説明する。もちろん三次元物体，とりわけ多 関節物体の動きの質を問われる作品制作の場合には詳細 なパラメータ設定が必要であるが，インタラクティブに 入力に応じて動作を変化させるシステムの場合には，動 きとしてのリアルさより外部からの刺激に応じた適切な 応答を生成できるかが問われる傾向にある。このような 場合, 人間は細部の動きよりも, 動作全体としての応答 内容の適切さや意味を重視する傾向があるためである.

\footnotetext{
* 原稿受付 2000 年 9 月 19 日

†大阪大学大学院基礎工学研究科 Graduate School of Engineering Science, Osaka University; 13 Machikaneyamacho, Toyonaka city, Osaka 560-8531, JAPAN

Key Words: motion generation, music factor, MIDI, 3D spring model.
}

それは，最近注目を集めているペット型ロボット，ある いは音や光のような刺激に反応するキャラクタグッズの 一般的な評価のされ方をみれば明らかである。このよう な商品に対する評価は,「動きのあいらしさ」のような漠 然とした雲囲気であり，関節角の精度ではない．ところ で，このように動きの正確さを厳密に追求しなくてよい デフォルメされた対象の CGによる動作生成を扱った研 究はまだ少なく，またインタラクティブ・トイとして実 態化, 商品化されているものについても現時点では動か すことが目的であり，外部の刺激に対する応答の動きの 適切性の評価にまでは至っていないのが現状である。

一方, 単純な音や光の刺激への応答ではなく, 音楽に 応じて CGに振り付けを行う研究は更に少ない. ディズ ニーのアニメーションや CMに代表されるように, 現在 では音楽と同期した CG の動作付けが普通のものとなり つつある。しかし，音楽と映像は最初から同時に生成さ れるのでなく別々に作られ，音楽に合うように映像の動 きを手動で補正せねばならない場合も少なくない。この 場合，たとえば音楽を差し替えたりフレーズの長さを変 化させたりといった大きな音楽構造に変化があった場合 はもちろん，テンポを調整しただけでも映像そのものの 作り直しを迫られる場合がある。一方，システムに音楽 を与えればその音楽にあった振り付けを自動的につけて くれると省力化されるのみならず，音楽に様々な変化を 何度でも与えてその都度振り付けの変化をみることがで きるようになり，作品を作る際の自由度を高めることが 期待できる。 
本論文では，上述したような機能を実現するプロト夕 イプシステムを制作し, 評価を行った結果について報告 する。

\section{2. 音楽に同期した動きの自動生成}

\section{1 従来の研究}

本論文に関連する研究例はまだそれほど多くはないが， 音楽と同期した動きを生成する研究の性格は，二つの分 類軸で区分される四つの象限で分類することができる。 その軸の一つは，システムに与えられる音楽が，MIDI 信号に代表される楽器演奏情報で与えられているか, 音 楽信号そのものとして与えられているかである。また， もう一つはリアルタイムに検出される音の高さ, 音の長 さ，音の強さ，音色などの音楽要素そのものを動きの生 成に用いているか, それとも音楽の解釈や構造・特徴の 分析結果も併用し，動きに踊りとしての意味を付与しょ うと指向しているかどうかである（Fig. 1)。この分類軸 によって，それぞれの研究が焦点を合わせている技術的 な課題の違いも明白になる。

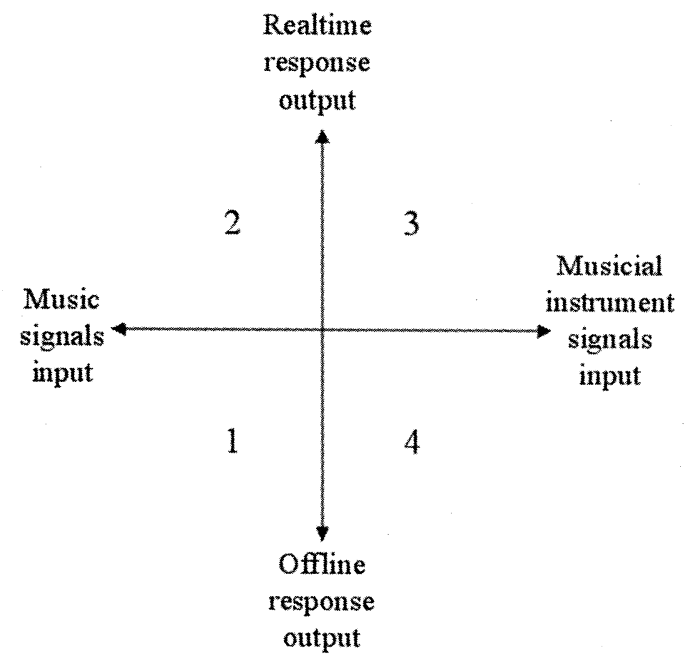

Fig. 1 A taxonomy of former researches and the stance of current research

たとえば，リアルタイム演奏に合わせた動きを追求し ている後藤らは音響信号としての音楽から拍節構造を認 識するリアルタイム・ビートトラッキング技術 [1-4] を開 発し，それを応用して音楽のビートに合わせて踊るバー チャルダンサーを構築した。ここではビートトラッキン グが研究の中心であり，CGの動作についてはあらかじ め決められた動きをりズムのパターンに合わせて繰り返 すというシンプルな生成方法をとっている．基本的にア ニメーションする物体の変更や形状変化は効かず，また， 音楽に合わせてダンスが新たに生成されるわけでもなく， あくまでビートをダンスとして可視化することを目的と した信号処理の延長線上にある研究である（Fig. 1 の第 2 象限)

一方，MIDI 信号そのものを，3DCGの人形の動作パ
ラメータとして与える研究もなされている [5]（Fig.1の 第 3 象限).こちらの入力は MIDI 音楽ファイルであるた めリアルタイム・ビートトラッキングを行う必要がない. したがって，音楽と動作パラメータとの対応付けが中心 課題となり，ユーザの好みで対応付けのルールを手動調 整可能なエディ夕としての機能に焦点があてられている. ただし，システムが音楽を構造的に解釈し，イメージに あったダンスを生成提示してユーザをサポートすること を目標としているわけではないので，音楽のイメージに あった動きをさせるようにパラメー夕を設定するには経 験が必要である。したがって，生成されたダンス自身が 音楽のイメージにあっているかどうかについては，評価 が難しいと述べられている [5].

\section{2 本研究の基本方針}

一方, 本研究の目的は, ユーザの与える MIDI 音楽 ファイルにふさわしいダンスアニメーションの自動生成 であり（Fig. 1 の第 4 象限），参考文献 [5] と同様 MIDI 信号が入力となる．ただ，参考文献 [5]のようにMIDI そのものの信号で関節角を制御する直接的な手法をとら ず，音楽の特徴変化がバネモデルの動きのパラメータ変 化に反映され，その結果新しい踊りが間接的に生成され るような生成アルゴリズムを提案する。

特に本論文で提案する手法では，与えられた音楽を 分析する際に，音楽の演奏情報である基本的音楽情報 （3.1.1に示す）と，その雲囲気や盛り上がりといった感 性的情報（3.1.2に示す）をそれぞれ抽出し，両者を動作

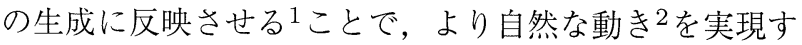
ることを試みる。これらを導入することによって，様々 な音楽の特徵に柔軟に対応し, それらが反映された動き を生成できる点で参考文献 [1-4] と，また音楽の雲囲気 にあった踊りが生成されるという視点からは参考文献 [5] と比較して，より良い振り付けを簡単に実現することが できるものと期待される。

また，動作生成に関して，本論文では CGで表現され た物体の動きに関する計算量を減らすため，運動と変形 可能な $3 \mathrm{D}$ バネモデルで表現された直方体内部に物体を 表現し, 動作コントローラを用いて音楽にあわせた連続 動作を実現する手法を提案する。この方法を用いれば直 方体の変形に比率して内部の複雑な物体を変化させる ことが可能であり [6]，しかも計算そのものは直方体一 個分のみでよい，たとえば，イスやテーブル，あるいは 車といったデフォルメ可能な物体を擬人的に取り扱って ミュージカル風に踊らせる芸術的効果も期待できる. 次 章では，ここで提案した手法を実現する仕組みについて 詳しく説明する。

\footnotetext{
1対象物の動きが音楽のリズムや感性情報にあっている こと.

2音楽の有り無しにかかわらず，対象物に固有の物理的 な性質を反映した，ユーザにとって違和感のない動き。
} 


\section{3. システムのアーキテクチャ}

本システムは，大きく三つのステージから成る (Fig. 2). それらは

1) 音楽の特徴抽出,

2) アニメーションする物体の 3D バネモデルによる表現,

3) 音楽の特徴に応じたアニメーションの生成

である。以下の各節で，それぞれについて説明する。

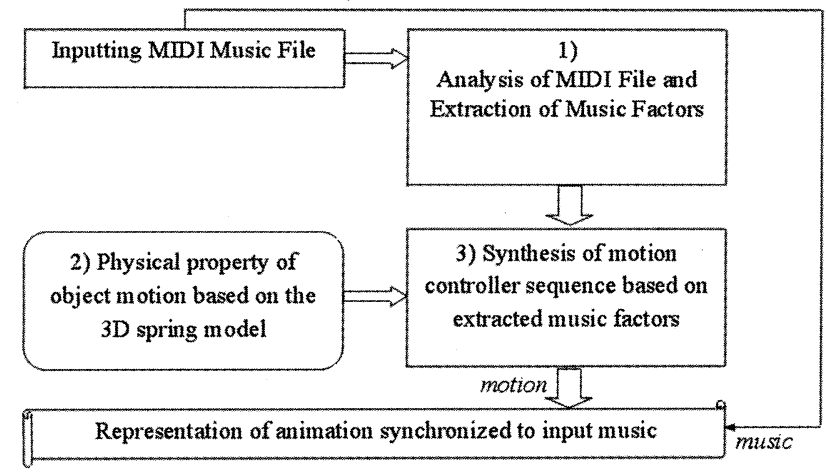

Fig. 2 System architecture

\section{1 音楽の特徵抽出}

本研究では, 音楽のパラメー夕を動作パラメー夕に反 映させることにより，自動動作生成を行う。まず，どの ような音楽要素を必要とするかを説明する前に, 音楽と 映像の調和について説明する。参考文献 [15-17]による と, こうした調和には, 構造的調和と意味的調和の二つ があると指摘されている. 構造的な調和とは音楽のテン ポやリズムと映像の動きや変化との同期による調和であ る。それについて，3.1.1で具体的に説明する，もう一 つの意味的調和とは，たとえば「明るい」印象の音楽と 「明るい」印象の映像の間に生じる意味の対応による調 和である。それについて, 3.1.2で述べる。

\subsection{1 基本的音楽情報の抽出}

本研究におけるアニメーションの合成では，入力され た音楽ファイルから抽出された音楽特徵量が動作を生 成する基本的な要素となる，音楽の入力ファイルは標準 規格である SMF（Stand MIDI File）[7]で与えられる. SMFのファイルに対して抽出アルゴリズムを用い, 分解 能 (division), 時間位置 (measure/beat/tick:MBT), テ ンポ (tempo), 拍子 (beat), 音の強さ (velocity), 音の 長さ (durationまたは gate time) といった情報を抽出す る。本論文における, SMFの時間の表記法にはMBT方 式 [8] が用いられる. MBT とは, 小節 (Measure) と拍 (Beat) とティック $(\mathrm{Tick})^{1}$ からなる時間表現方法のこと である。

本システムでは，音楽のテンポ，拍子と小節における 位置によって各動作の開始時刻を決め，音楽に同期する

\footnotetext{
1ティックは, 分解能 (タイムベース)の最小単位を表し ている $[7,8]$.
}

動作の表現を可能としている．曲の途中で，新たなテン ポや拍子を設定する場合でも，それらの MBTによる時 間位置から, 絶対的な曲のスピードとリズムの变奏され る位置を計算し, 音楽に同期する動作の開始時刻を決定 することができる。

\section{1 .2 感性的音楽情報の抽出}

音楽の流れには盛り上がりが存在し, 我々はその変化 で音楽の緩急を感じ, 音楽より受けるイメージも大きく 左右される. 感性情報理論の角度では, 本論文で討論さ れる音楽の盛り上がり度は感性情報の一部である。感性 情報処理論によって感性情報が個人差とあいまい性があ る [20]ので，本文の音楽の盛り上がりも個人差とあいま い性がある。これまでこの盛り上がりの度合いを計算す る方法がいくつか提案されている $[9,10]$. 一方，音楽の 盛り上がりと同様に，ダンスの流れにも盛り上がりがあ る。本論文では，踊りを生成するという目的にあわせて 小節または拍における盛り上がり度を計算する方法を提 案する，文書の流れとしては，本節では音楽に関する盛 り上がり度を説明し，3.3.2 と 3.3.3で動きに関する盛 り上がり度を説明する。

\section{(1) 音楽の盛り上がり度と音の強さの関係}

参考文献 [8]による，MIDIにおいて「音の強さ」の要素 となる「音の強弱」を表わすのが「ベロシティ(velocity)」 である.ベロシティは音量に対応し，0 から 127 の数值 が割り当てられ，数值が大きい程，音も大きくなる．べ ロシティは音源により音色にも対応し，大きい音は明る く，小さい音は柔らかくなるなど音色変化も伴っている． そういうある範囲内の単調性を反映するため, 本論文で は，音の高さ，音色，音の長さが同じの場合，単音列に おいて, 音楽の盛り上がり度が音の強さと正比例関係を 保つと仮定する。

\section{(2) 音楽の盛り上がり度と音長の関係}

普段には，人間の耳から聞いている音は「音の高さ」 「音色」「音の大きさ」という三つの要素からなる。そし て一番重要なことは, 音というのは必ず，時間的な変化 をするということである [8]. 物理的には，音の長さが 音のエネルギーの累積効果に影響を与える [17].つまり， 長い音が短い音より多くの音のエネルギーを釈放する. 以上の単調性を反映するため, 以下のように仮定する. 本論文では, 音の高さ, 音色, 音の強さが同じとし, 音 の減衰を考えない場合, 単音列において, 音楽の盛り上 がり度が音の長さと正比例を保つと考える。

\section{(3) 音楽の盛り上がり度と音の数の関係}

音楽の和音と単音の間および音符と休符の間など，強 い響きを人間に与える $[17,19]$. また，ユニゾン (unison: いくつかの楽器で同じ高さあるいはオクターブで音を重 ねる)によっても和音と類似の「強い」響きを人間に与 える [17]. それらの性質を反映させるため, 本論文では, 
簡略化するため，音色 ${ }^{1} な と ゙$ 他の要素をまず考えないと， 単純に同時に音の数が増えたら音楽の盛り上がり度も上 がると仮定する。

(4) 拍エネルギーと小節エネルギー

音楽の認知理論によると，人間は音の長さ，音の強 さ，テンポ等の要素に対しては，相対的に感じることが 多い $[17,19]$. 本論文で論じる音楽の盛り上がり度にも相 対的な量的の度合いと考える。ここで，その曲に当たり， 基音（基音の長さが一拍の長さと等しい）の最大強さに 達する表現は音の表現の目安としたら，一拍内の他の音 は基音で正規化して相対的に表現する。

本論文では，拍の盛り上がり度はその拍内のすべての 単音の相対的表現值の総和と定義する。また，拍の盛り 上がり度を拍エネルギーと名づける。この定義は (1) 式 に示す。ここで, $M a x D_{b}$ は拍 $b^{2}$ の長さとし，MaxVを Velocityの最大值とし, $D_{i}{ }^{3}, V_{i}$ はそれぞれ拍内の単音 $i$ の長さと強さとする場合, $\left(D_{i} / M a x D_{b}\right)\left(V_{i} / M a x V\right)$ を 音 $i$ の相対的表現值と考えられ，それを単音エネルギー と定義すると, $E_{b}(b)$ は $b$ 小節におけるすべての単音エ ネルギーの総和となる．なお， $k$ は $b$ 拍に発音する音の 数である.

$$
E_{b}(b)=\sum_{i=1}^{k} \frac{D_{i}}{\operatorname{Max} D_{i}} \frac{V_{i}}{M a x V}
$$

同様に，小節の盛り上がり度は小節エネルギーとなづけ， それを (2) 式のように定義する.ここで, $E_{m}(m)$ は $m$ 小節目の単音のエネルギーの総和である。なお， $k$ は $m$ 小節に含まれる音の数である. また, $D_{i}, V_{i}, \operatorname{Max} V$, $\operatorname{Max} D_{i}$ は $(1)$ 式と同じ設定である.

この小節のすべての音が休止した場合, $E_{m}(m), E_{b}(b)$ は 0 になる。また，MIDI デー夕の性質により，MaxV は常に 127 となる。また，電子楽器の最大同時発音数制 限があるので $[7], E_{b}$ にも上限がある.

$$
E_{m}(m)=\sum_{i=1}^{k} \frac{D_{i}}{M a x D_{i}} \frac{V_{i}}{M a x V}
$$

\section{（5）音楽の感性情報から動きへ}

3.1 の冒頭部分に述べたように，動きと音楽の意味的 調和関係があり，いわゆる，同じな感性情報を持つ音楽 と動き，たとえば「強い」音楽と「強い」動きを組み合 わせた場合,「共鳴現象」[18] を生じる. その意味的調和 を反映するため, 本論文では, 盛り上がり度というパラ

${ }^{1}$ 本文では, 簡略化のため, 楽器の増減による音色の影 響にかかわらず，ただの音の数を増えると考える。

${ }^{2}$ 曲中で，テンポによる，基音の長さが必ずしも一定で はない。ゆえに，拍の記号をつける。

${ }^{3} D_{i}$ には，音 $i$ がその音のキーオフまでの持続時間では なく, 拍 $b$ 内の持続時間である。 $D_{i}$ は所在する拍 $b$ の 拍線を超えれば，拍線により若干のサブイベントに分 ける，その超える音は次の拍 $b+1$ で統計される.
メータによって動作と音楽を対応付ける。

(a) ダンスの基本動作について考察すると，本論文で は平行移動スピードが「大きい」，ジャンプが「高い」， 回転角度が「大きい」などを対応付ける，対応時間につ いては，ダンスのルールによって，一般には，ダンスの 基本動作は一拍内で終了する ${ }^{4}$.

(b) 一連の基本動作からなるダンス基本動作の組合せ を考察すると,「難度が高い」基本動作（たとえば，ジャ ンプが平行移動より難しい, 3 回転が 2 回転より難しい など）がある動作組合せのほうがより「共鳴現象」を生 じやすいと考える，また組合せの「複雑度が高い」組合 せ（たとえば，人間の動きには慣性があるので，三つの 動作の中に，二つ目が急にストップすると，より完成度 が難しくなるので, 音楽の盛り上がりとの「共鳴現象」 を生じやすい）がより「共鳴現象」を生じやすいと考え る．対応時間については，本論文では，簡略化のため，

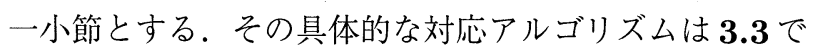
更に説明する.

\section{2 アニメーションする物体の $3 \mathrm{D}$ バネモデル による表現}

\subsubsection{D バネモデル}

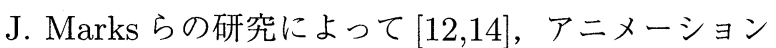
として表現された対象物 (animated figure) を提案され た.アニメーションの中では, 元々動けないものが擬人 化される場合が多い，たとえば，ひねりをする擬人化さ れたダンスをする木や飛んでいる皿と瓶などの例が少な くない. 本研究では，そういった animated figure を対 象とし，それを動かすことを目的としている。

仮想空間内で柔らかい物体や弾性のある物体を表現す る手法としてバネモデルが提案されている [11] が, 本論 文では直方体の各頂点をバネで結んだ格子状のバネモデ ルを用いる (Fig. 3) . 複雑な形状を極小直方体の格子で 表現し物理的にリアルな動きを表現することも試みられ ているが，現時点ではできるだけ少ない計算量で自然な 動きを再現できればよいという立場に立っている $[12,14]$. したがって，モデリングのデータとしてバネモデルの各 頂点からのベクトルを与えることにより，バネモデルの

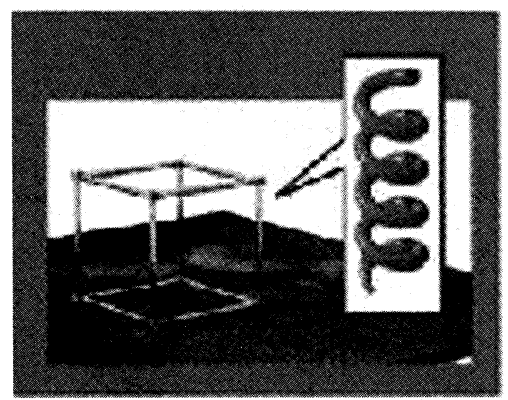

Fig. 3 3D spring model

\footnotetext{
${ }^{4}$ 基本動作が一拍以上で終了するケースもあるが，一拍 内に終了させるのは計算の簡略化のためである.
} 
変形に伴い中のモデルも変形する。これにより，直接複 雑な形状のモデルを扱うより計算量を減らすことがで きる。

\subsection{2 バネモデルの変形ルール}

実際のバネの動作は (3) 式を考えることによりシミュ レートできる。ここで $F$ はバネにかかる力， $x$ はバネの のび， $K$ はバネ定数， $L$ はバネの自然長， $D$ はバネのダ ンピング定数, $t$ は時間を表す.

$$
F=-K(L-x)-D \frac{d x}{d t}
$$

\subsection{3 基本動作}

バネモデルに与える動作の最小単位となる基本動作と して大きく分けて Shear, Twist, Splay, Scaleの 4 種 類 [13] を考える（Fig. 4)．つぎに，それらを組み合わせ ることによってダンスを表現できることを説明する。

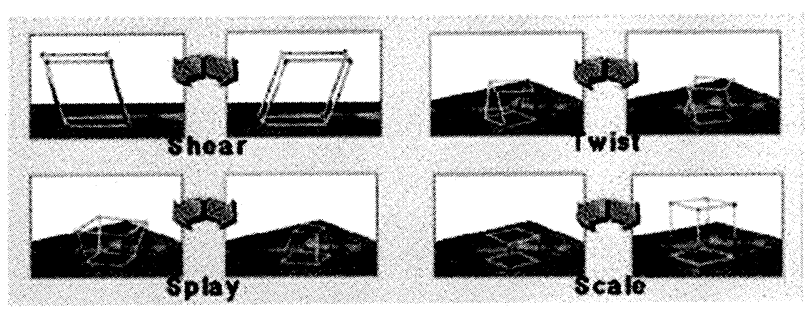

Fig. 4 Fundamental motions

ダンスといえば，一般には，人物の体の移動，傾き，ひ ねりや回転, ジャンプなどの基本動作を組み合わせて表 現できるものである，本研究では，平行移動には本節の (4)に示される ScaleX, ScaleYにより完成させ，傾きに は本節の (1) に示される ShearX と ShearYにより完成さ せ，ひねりや回転には本節の (2) に示される Twistによ り完成させ，ジャンプには本節の (4) に示される ScaleZ により完成させる ${ }^{1}$. また，発進する時に足を長くした り，興奮するときに頭が大きくなったりするなどのよう な人間ではなく animated figure が特有である局所の拡 大性の表現には，本節の (1) に示される Splay による反 映させる。

さらに，本手法では，ある瞬間のバネモデルの頂点の 位置により，その瞬間の対象物体の形状をレンダリング する．また，3.2.4に述べる基本動作の開始時間と持続時 間によって，バネモデルの減衰状態が決まる。したがっ て，前の動作の持続時間が終わるまで，完全に減衰する わけではないので，次のスタートする基本動作との複合 運動をさせる.

\section{(1) Shear}

バネモデルの上部が傾き同時にモデル自身の傾きを促 すという動作であり，この動作には傾く方向がX軸方向

1ここでは，簡略化のために，人物の重量と弾性係数が 一定であると設定したため，そのジャンプによる自由 落下運動も同時に完成させる，ただし，3.2.4に述べ る基本動作の引数によってジャンプの高さが違う.
と $\mathrm{Y}$ 軸方向の 2 種がある.

(2) Twist

バネモデルの上部を Z 軸（仮想空間内の鉛直方向）中 心にひねり，その反動による回転を促す動作である.

(3) Splay

バネモデルの上部が拡大・縮小する動作である。

\section{(4) Scale}

バネモデルが押しつぶされたようになり，その反動に よるモデルの移動を促す動作であり，この動作には $\mathrm{X}$, $\mathrm{Y}$ 軸の平行移動, $\mathrm{Z}$ 軸の跳躍の 3 種がある.

したがって，Shearは 2 軸を，Scaleは 3 軸を考える必 要があるため，実質的には動作の選択肢は 7 種となる. この基本動作の組合せにより，物体の複雑な動きを表現 する.さらに，アニメーションに重力要素も加えれば, 自然な動きの表現ができる。

\subsection{4 動作コントローラによる物体の連続的な動き の構成}

本研究では，音楽にあったダンスアニメーションは動 作コントローラ (Motion Controller: MC) の時系列か らなる（Fig. 5). MC は一つの動作パターンと考えら れ，一連の最小動作単位 (Cell) からなる。一つの Cell を与える際には，四つのパラメー夕を付与する，その四 つのパラメータの各時刻の值によって，バネモデルの頂 点位置の計算を行い，モデルにあてはまる対象の瞬間の フレームをレンダリングさせる。ここでは，各基本動作 において，モデルの各頂点に与える力の相対的方向 2 を 定数とし，また，初期設定がいるバネモデルの初期位置 また，モデルの各頂点のを結びつけるバネの弾性係数な どのパラメータについては，実験とした現時点では，す べて定数としている。ただし，実用段階では，CADの ようなエデイ夕環境を与えることによる，初期パラメー 夕の設定も可能である.

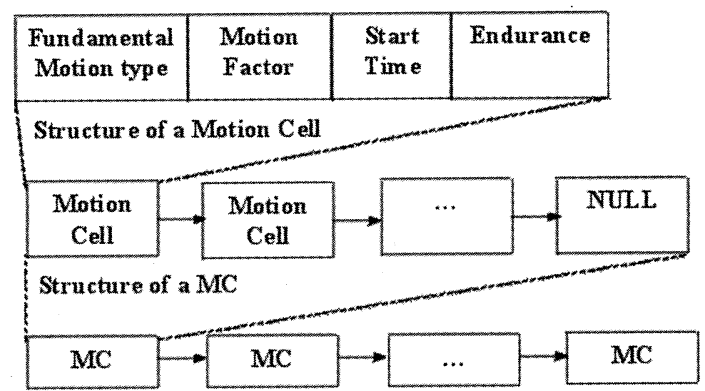

Fig. 5 Structure of motion controller sequence

1）基本動作の種類：先に述べた 7 種の基本動作のど れを選択するかを示す. 0 から 6 までの数值が動作 種類番号を表示する。

2) 基本動作の引数 : - 1.0 から 1.0 までの数字を与え

\footnotetext{
${ }^{2}$ 頂点の瞬間座標が時刻によって違うので，力の方向は その瞬間の頂点の法線による確定する。
} 


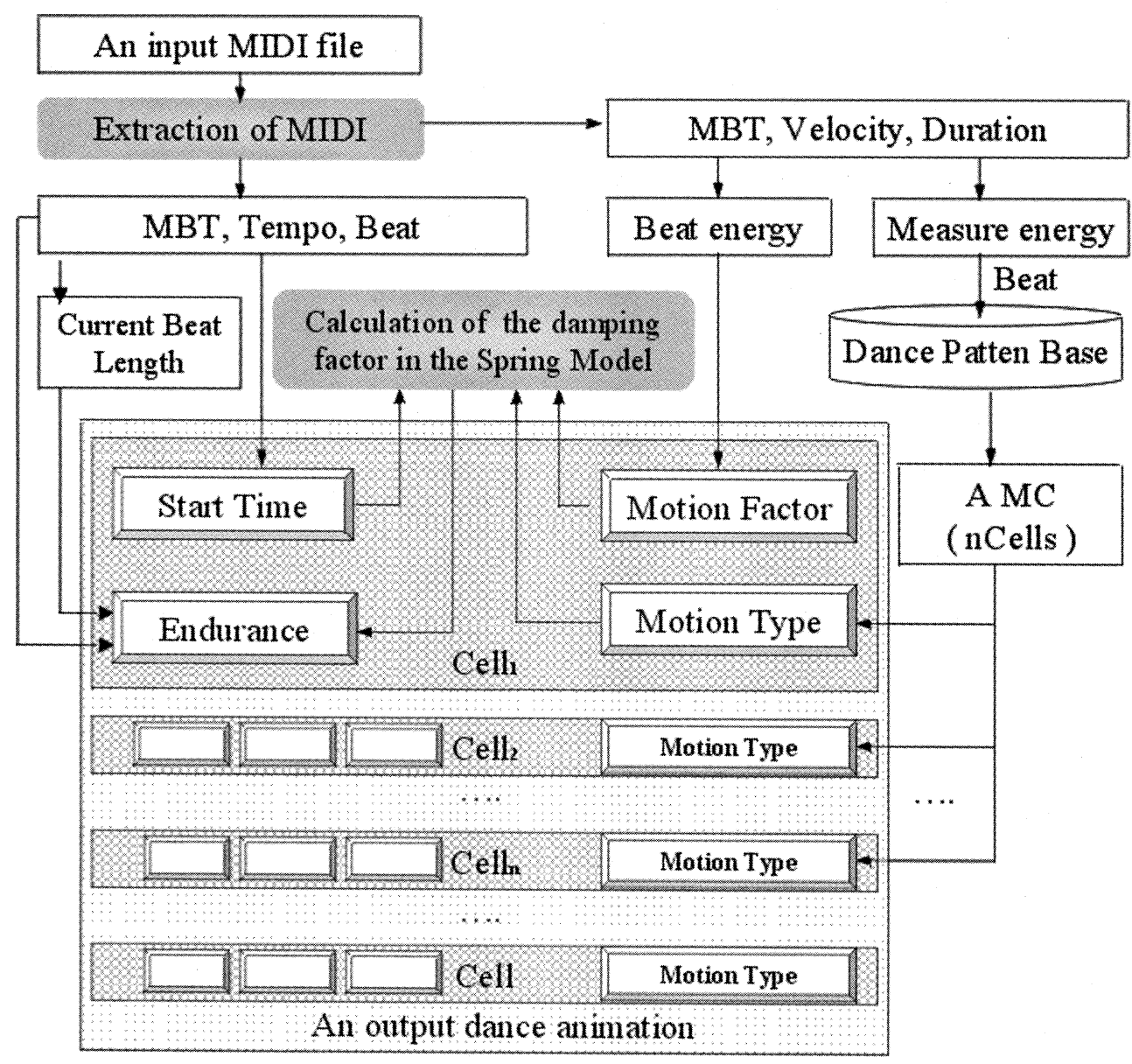

Fig. 6 Generation of dance scene by music factors

る. 数字の正負号は基本動作の変化方向を示し ${ }^{1}$, 数字の絶対值が頂点に与える力の相対的強さを示 し，それによる基本動作の程度の変化を表現する。

3) 開始時刻：基本動作の開始する時刻を決める。単 位は $\mathrm{ms}$ である。

4) 持続時間：動作の持続時間を決める. 持続時間が 0の場合には, Cell の開始時刻からその次の Cell の開始時刻まで開始姿勢を保つことになる。

\section{3 音楽の特徴に応じた動作の生成}

\subsection{1 基本的な動作パラメータ}

ここでは，音楽のリズムによく合い，盛り上がり度を 反映した連続動作を生成する手法を説明する（Fig. 6). 一つの動作を生成するために，決定するパラメー夕は以 下のようである。

1）基本動作単位のパターン（すなわち 1 小節中の各 拍に対応する基本動作の種類と運動方向）：時間位 置と小節エネルギーと拍子から計算する。

2) 動作の強さ：時間位置と拍エネルギーに基づいて 決定する.

3）動作開始時刻：時間位置とテンポと拍子から決定

1平行移動なら正負 180 度の変化に与え, 回転運動なら 正反時計周りの変化に与える.
する。

4) 動作の持続時間：動作の種類と強さから決定する. 以下，それぞれの決定方法について各節で述べる。

3.3.2 基本動作の種類と相対運動方向の決定 実際のダンスは数個の基本ダンスステップからなり， また，音楽の一拍ごとに複雑な動作の変化がありうるが, 本論文では, 簡略化のため一つの拍には一つの基本動作 単位を対応づけ，一つの小節には一つの動作パターン (動 作コントローラ) を対応づける．3.1.2で述べたように， 小節エネルギー $E_{m}$ が音楽の小節の盛り上がりを近似 的に反映している。また，曲によって，小節エネルギー の範囲がそれぞれ違うので， $m$ 小節の小節エネルギー $E_{m}(m)$ が $E_{m}$ の最大值と最小值により正規化を行い, 動作の盛り上がり度を得る.MotionClimaxRank(以下 $M C R$ と略記する) を動作パターンの盛り上がり度とす ると，小節エネルギー $E_{m}(m)$ ，小節エネルギーの最小 值 $\min \left(E_{m}\right)$ ，小節エネルギーの最大值 $\max \left(E_{m}\right)$ を用い て,(4)式のように表現することができる.

$$
\operatorname{MCR}(m)=\frac{E_{m}(m)-\min \left(E_{m}\right)}{\max \left(E_{m}\right)-\min \left(E_{m}\right)}
$$

ここでは，計算された動作パターンの盛り上がり度 $M C R$ と拍子によって，パターンデータベースから条件 
Table 1 Data example in pattern database

\begin{tabular}{|c|c|c|c|c|c|c|c|c|c|c|}
\hline \multirow{3}{*}{$\begin{array}{c}\text { Beat } \\
\text { (Numerator) }\end{array}$} & \multirow{3}{*}{$\begin{array}{c}\text { Climax of } \\
\text { Motion Patten }\end{array}$} & \multicolumn{9}{|c|}{ Motion Controller ( FM:Fundamental Motion; DIR:Direction ) } \\
\hline & & \multicolumn{2}{|c|}{$\mathrm{Cell}_{1}$} & \multicolumn{2}{|c|}{$\mathrm{Cell}_{2}$} & \multicolumn{2}{|c|}{$\mathrm{Cell}_{3}$} & \multirow[t]{2}{*}{$\mathrm{Cell}_{4}$} & \multirow[t]{2}{*}{$\ldots$} & \multirow[t]{2}{*}{$\mathrm{Cell}_{10}$} \\
\hline & & FM & DIR & FM & DIR & FM & DIR & & & \\
\hline 3 & $\mathrm{~S}: 0.00<=M C R<0.33$ & ScaleX & + & ScaleX & + & ScaleX & + & NULL & ... & NULL \\
\hline 3 & $\mathrm{~S}: 0.00<=M C R<0.33$ & ScaleX & + & ScaleX & + & ScaleX & - & NULL & ... & NULL \\
\hline 3 & $\mathrm{~S}: 0.00<=M C R<0.33$ & ScaleX & + & ScaleX & + & ScaleY & + & NULL & $\ldots$ & NULL \\
\hline 3 & $\mathrm{~S}: 0.00<=M C R<0.33$ & ScaleY & + & ScaleY & + & ScaleY & + & NULL & $\ldots$ & NULL \\
\hline 3 & $\mathrm{~S}: 0.00<=M C R<0.33$ & ScaleY & + & ScaleY & + & ScaleY & - & NULL & $\ldots$ & NULL \\
\hline 3 & $\mathrm{~S}: 0.00<=M C R<0.33$ & ScaleY & + & ScaleY & + & ScaleX & + & NULL & . & NULL \\
\hline 3 & $\mathrm{M}: 0.33<=M C R<0.67$ & ScaleX & + & ScaleX & + & ShearX & + & NULL & $\ldots$ & NULL \\
\hline 3 & $\mathrm{M}: 0.33<=M C R<0.67$ & ScaleY & + & ScaleY & + & ShearY & + & NULL & $\ldots$ & NULL \\
\hline 3 & $\mathrm{M}: 0.33<=M C R<0.67$ & ScaleX & + & ScaleX & + & Twist & $\operatorname{Rt}(-)$ & NULL & $\ldots$ & NULL \\
\hline 3 & $\mathrm{M}: 0.33<=M C R<0.67$ & ScaleY & + & ScaleY & + & Twist & $\operatorname{Rt}(-)$ & NULL & & NULL \\
\hline 3 & $\mathrm{~L}: 0.67<=M C R<=1.00$ & ScaleX & + & ScaleX & + & ScaleZ & $\mathrm{Up}(+)$ & NULL & $\ldots$ & NULL \\
\hline 3 & $\mathrm{~L}: 0.67<=M C R<=1.00$ & ScaleY & + & ScaleY & + & ScaleZ & $\mathrm{Up}(+)$ & NULL & ... & NULL \\
\hline
\end{tabular}

を満足する動作コントローラが選ばれる．Table 1 に 3 拍子の音楽に対応するパターンデータベースの一部を示 す。一つのパターンの中に含まれる動作 Cell の数は小節 内の拍の数で決められるので, 動作コントローラは有限 個の基本動作 Cell からなる ${ }^{1}$. Table 1 では, $M C R$ を三 段階にわけている. $M C R$ と Table 1 によって，具体的 に対応する動作コントローラは以下のように決定される。

a.) $0.00 \leqq M C R<0.33$ : 音楽が比較的おちついた静 かな状態であることを示す．したがって，動作の速さは 弱く, 動きは平行移動を中心とする. 表の 1 行目から 6 行目までの動作コントローラ中から一つランダムに選ば れる.

b.) $0.33 \leqq M C R<0.67$ : 音楽はやや盛り上がりつつ ある。これに対応して, 動作の速さは普通となり, 動き にも傾きとひねりが付与される。表の 7 行目から 10 行 目までに相当する.

c.) $0.67 \leqq M C R \leqq 1.00$ : 音楽はクライマックスにさ しかかり, 非常に盛り上がっている。これに応じて, 動 作の速さは速く，動きにはジャンプが付与される．表の 11 行目と 12 行目の動作コントローラからどちらかいつ が選ばれる。

以上のように選択された動作コントローラで，一連の 基本動作 Cell の動作種類が決められる.

\subsection{3 動作の強さの決定方法}

前節で述べたように，小節の盛り上がりによって動作 パターンが決まる。節エネルギーは拍エネルギーの累 積值であるので, 小節の盛り上がり度が大きければその 中の各拍に扔ける盛り上がり度も平均的に大きい。しか

1 一般には，拍子は 10 を超える可能性が少ないので，一 つの動作コントローラに含む基本動作数は最高 10 個 とする.
し，同一小節内にも平均すれば見分けがつかなくなるよ うな微妙な変化がある場合が少なくない. 拍による差を 動作に反映させることによって微妙な動きの差を拍ごと に出すことができるようになる，3.1.2で述べたように， 拍エネルギーは基本動作 Cell の盛り上がり度に対応する ので，それを基本動作 Cell のパラメー夕決定に反映する ことで，基本動作の動きを微調整する。

基本動作の盛り上がり度を MontionFactor（MF と 略記する）とし，(5) 式で定義する。ここで， $E_{b}(b)$ は $b$ 拍のエネルギー, $\min \left(E_{b}\right)$ は拍エネルギーの最小值, $\max \left(E_{b}\right)$ は拍エネルギーの最大值である.

$$
M F(b)=\frac{E_{b}(b)-\min \left(E_{b}\right)}{\max \left(E_{b}\right)-\min \left(E_{b}(b)\right)}
$$

(5) 式で計算される $M F$ の值は常に正である. 一方, 3.3.2で選ばれた動作パターンの $\mathrm{MC}$ では, その $\mathrm{MC}$ 中 の各動作 Cell の運動方向が正であるか負であるかだけが 決められており，その量は $M F に$ に比例して与えられる。 すなわち，MFが大きければ長く，あるいは強くその動 きを行うことになる。

なお，X軸（または $\mathrm{Y}$ 軸）に沿って同じ方向に動きす ぎ視野から消えてしまわないように，視野外に出た場合 は自動的に 180 度方向転換する.

\subsection{4 音楽と動作の同期}

本方法では，各動作がリズムに合うよう一拍が一つの Cell に対応付けられ, 各 Cellの開始時刻は各拍の開始時 刻位置から算定される。

一方，拍に対応する動作 Cell の持続時間は，(6) 式で示すように, 動作タイプMotionType (MT と略 記する) と動作引数 $M F$ からバネのダンピング時間 
$\operatorname{Damp}(M T, M F)^{1}$ で計算される.ここで, $C B L$ は当 該拍の長さ, Enduranceは持続時間である.

$$
\text { Endurance }=\min (\operatorname{Damp}(M T, M F), C B L)
$$

特別な例として，たとえば拍エネルギー $E_{b}$ が 0 の場 合は (5) 式で $M F$ が 0 になるので (6) 式から持続時間も 0 となり, 急ストップの効果が得られる.

以上より, 各基本動作 Cell のパラメータがすべて与え られ，3D バネモデルの (3) 式で示されるバネの減衰原 理に基づいて時間ごとのオブジェクトの頂点位置を計算 し, 全体のアニメーションの動作が出力される.

\section{4. 評価実験}

\section{1 プロトタイプシステムの製作}

今回のプロトタイプシステムの構築は WindowsNT上 でVisual C++を用いて行われた。 プロトタイプシステ ムは生成部と再生部に分けられる。

生成部では, MIDI 音楽ファイルが入力された後, 前 節で述ベたアルゴリズムにしたがって，音楽の分析と 特徵抽出が行われ, 最終的に, 音楽に合った動作コント ローラ時系列の自動生成が行われる。

再生部では, 音楽と生成されたアニメーションを組 合せて同期して再生することが行われる.MIDI 音楽は MCI(Media Control Interface) を用いて再生され, 動 画はOpenGL を用いて描かれる。動作は3D バネモデル の中にFig.7に示すようなチェスのキングをあてはめて 表示した. 具体的な動作の例を Fig. 8 と Fig. 9 に示す. Fig. 8 はひねりが入ったワルッのステップの例であり, Fig. 9 はジャンプが入ったワルッのステップの例である.

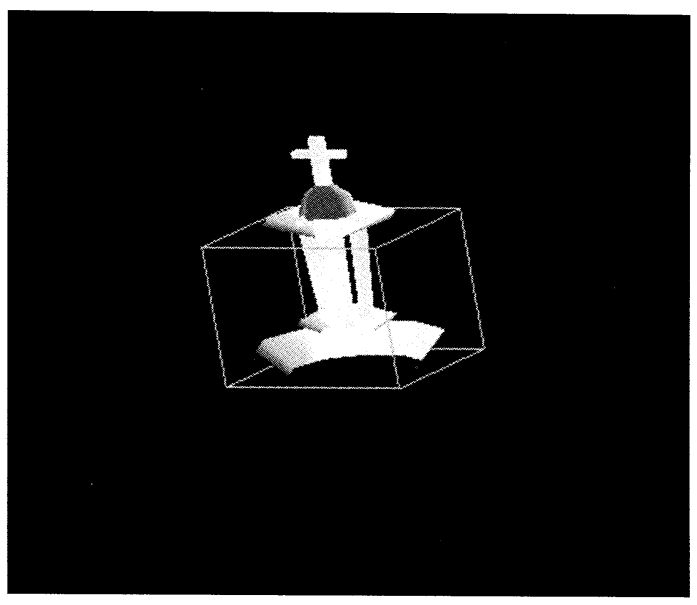

Fig. 7 Simulation sample(A dancing king)

\section{2 評価結果}

自動生成された動作と音楽とが適切に対応しているか どうか評価実験を行った。具体的には, ワルッ 2 曲, 夕 ンゴ 2 曲, ジャズ 1 曲, ディスコ 1 曲, クラシック 1 曲 計 7 曲について, 各曲の 30 小節ぐらいを入力音楽とし

\footnotetext{
ここで, バネの 2 次減衰時間とする。
}

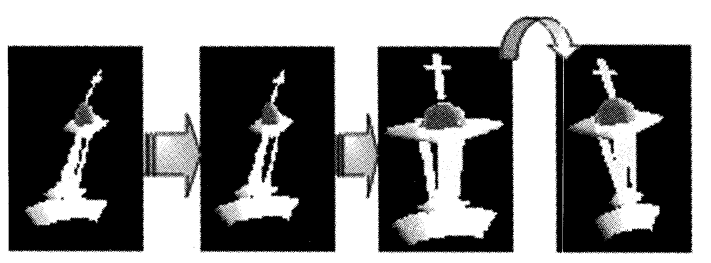

Fig. 8 An example of twist pattern for waltz

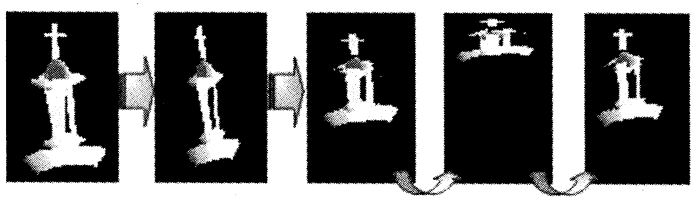

Fig. 9 Another example of jump pattern for waltz

て, 動作生成アルゴリズムにより動作を生成した。生成 した動作は入力音楽を同時にアニメーションとして呈示 し, 生成した動作と入力音楽の適合性を被験者 5 名に評 価してもらった。

評価の手法としては, 以下の三つの採点基準に対して それぞれ5段階の評価をしてもらった。

1）生成された動作が音楽のリズムに合う度合い。こ こで, 点数は 5 (合っている)，4（ほほ合ってい る)，3（合わない場合が多い）, 2（合っていな い）１（まったく合っていない）から選ばせる。こ こで, 3.1 の冒頭部分に述べたように, 音楽と踊り の構造的な調和について感性評価を行う.

2) 生成された動作パターンが音楽の盛り上がりに合 う度合い。ここで, 点数は 5 (合っている)，4(ほ ほ合っている)，3(合わない場合が多い)，2（合っ ていない)，1(まったく合っていない）から選ば せる。ここで, 3.1 の冒頭部分に述べたように, 音 楽と踊りの意味的な調和について評価する。なお， 特に「強い」のように軽重感にたいして感性評価 を行う。

3）全体としてみたアート的な感覚. ここで, 点数は, 5 (たいへん良い)，4（良い）, 3 (普通), 2（悪 い，1（たいへん悪い）から選ばせる。ここで, 音 楽と踊りの意味的な調和について評価するが, 特

・に全体のムードについて感性評価を行う。

さらに, 個別に長所と短所について自由形式でコメン 卜をもらった. Table 2, Table 3, Table 4 に評価結果 を示す.

\section{3 評価結果の分析}

生成した動作と音楽りズムの適合性の評価について は, Table 2 に示すように, 全体としては, 比較的高い 評価が得られているが (平均で 3.5 ), ジャンル別にみる と, タンゴ, ワルッが比較的評価が高いのに対し, ジャ ズは低くなっている，この理由としては,「タンゴ，ワル ツは踊りのイメージがすぐわく」のに対し、「ジャズに合 わせて踊る」ことは実際に少ないため，ジャズのリズム 
Table 2 An evaluation of five degrees of the fitness between synthesized motions and music rhythm

\begin{tabular}{|c|c|c|c|c|c|c|}
\hline Input SMF & Testee A & Testee B & Testee C & Testee D & Testee E & Average \\
\hline Walt $_{1}$ & 5 & 3 & 4 & 3 & 4 & 3.8 \\
\hline Walt $_{2}$ & 4 & 3 & 4 & 3 & 4 & 3.6 \\
\hline Tango $_{1}$ & 4 & 4 & 4 & 4 & 3 & 3.8 \\
\hline Tango $_{2}$ & 5 & 4 & 4 & 4 & 3 & 4.0 \\
\hline Jazz & 3 & 2 & 3 & 2 & 2 & 2.4 \\
\hline Disco & 4 & 3 & 4 & 3 & 3 & 3.4 \\
\hline Classic & 5 & 4 & 5 & 2 & 3 & 3.8 \\
\hline \multicolumn{7}{|l|}{} \\
\hline
\end{tabular}

Table 3 An evaluation of five degrees of the fitness between synthesized motion pattern and music climax

\begin{tabular}{|c|c|c|c|c|c|c|}
\hline Input SMF & Testee A & Testee B & Testee C & Testee D & Testee E & Average \\
\hline Walt $_{1}$ & 4 & 2 & 3 & 4 & 3 & 3.2 \\
\hline Walt $_{2}$ & 4 & 2 & 4 & 3 & 4 & 3.4 \\
\hline Tango $_{1}$ & 3 & 3 & 3 & 2 & 3 & 2.8 \\
\hline Tango $_{2}$ & 4 & 3 & 4 & 2 & 2 & 3.0 \\
\hline Jazz & 3 & 3 & 3 & 4 & 2 & 3.0 \\
\hline Disco & 4 & 2 & 4 & 4 & 3 & 3.4 \\
\hline Classic & 4 & 3 & 4 & 3 & 4 & 3.6 \\
\hline \multicolumn{7}{|l|}{} \\
\hline
\end{tabular}

Table 4 An evaluation of five degrees of the artistry impression on whole animation

\begin{tabular}{|c|c|c|c|c|c|c|}
\hline Input SMF & Testee A & Testee B & Testee C & Testee D & Testee E & Average \\
\hline Walt $_{1}$ & 2 & 2 & 3 & 4 & 4 & 3.0 \\
\hline Walt $_{2}$ & 2 & 2 & 4 & 3 & 4 & 3.0 \\
\hline Tango $_{1}$ & 2 & 3 & 3 & 4 & 3 & 3.0 \\
\hline Tango $_{2}$ & 2 & 3 & 4 & 3 & 2 & 2.8 \\
\hline Jazz & 3 & 2 & 3 & 2 & 2 & 2.4 \\
\hline Disco & 3 & 3 & 4 & 3 & 3 & 3.2 \\
\hline Classic & 2 & 3 & 4 & 4 & 3 & 3.2 \\
\hline \multicolumn{7}{|l|}{} \\
\hline
\end{tabular}

と動きとのマッチングそのもののイメージが得にくい点 があったようである（被験者 B,Dの意見）.

一方，生成した動作パターンと音楽盛り上がりの適合 性の評価については, Table 3 に示すように, 全体とし てはリズムとの適合性より少し低い值となっている（平 均で 3.2). ジャンルでは, ワルッ, ディスコとクラシッ クが比較的評価が高いのに対し，タンゴは低くなってい る。これは, タンゴに拈いては, 音楽的盛り上がりが頻 繁に起こっているが，それに対応した「切れの良い」動 作が必ずしも完全に再現されていない点が原因となって いるようである (被験者 $\mathrm{D}, \mathrm{E}$ の指摘).

全体としてのアート的感覚の評価については, Table 4 に示すように，平均で 2.9 と，三つの評価基準の中では 一番低い評価点となっている．特に芸術性という観点か
らは,「リズム」と「盛り上がり」のようなプリミティブ な要素だけでなく，音楽の感情的な解釈やそれに応じた 細かい動きが必要であると考えられるが，この点につい ては，まだまだ不十分であることも確認できた。

また，自由形式のコメントとしては，以下のようなも のが得られた。

・「ワルッとクラシックに合わせる動きがイメージに 合っていて良かったと思う」（被験者 A,B,C,D）

・「ディスコの印象が一番よかった。動きにバリエー ションが多い. 音が止まっている時動きが止まった り，音が大きいところで大きな動きに与えたりして， 盛り上がりにあっていると思う」（被験者 $\mathrm{A}, \mathrm{E}$ )

・「すべるような動きがワルツっぽいと思う」（被験者 D) 
・「クラシックの音楽に合わせる動きは流れるような 音楽のイメージにあっていると思った」(被験者 $\mathrm{E}$ )

・「タンゴ1では, 動きが全体として小さい」(被験者 E)

・「全体的には, ダンスなので, オブジェクトが人間の ほうがわかりやすい（評価しやすい）と思う」(被 験者 $\mathrm{C}$ )

-「クラシックでは, 曲全体を画面全体に割り振って いるので，頭部分はおとなしすぎる，退屈してしま う」(被験者 D)

以上の評価結果とコメントに基づいて総合評価挹よび 今後の課題をまとめると, 以下のようになる.

1）全体としては,「リズム感」「盛り上がり度」に関し ては，ほぼ対応した動きが生成できている。

2）一方，芸術性に関しては，音楽の感情的解釈やそれ に応じた細かい動作が欠けて扔り，不十分である。

3) 今後の課題としては,

(1)リズム感，盛り上がり度以外のファクター の考慮,

(2)オブジェクトの細かい動きの表現 等が上げられる。

\section{5. おわりに}

本稿では，音楽に応じたアニメーションを生成するア ルゴリズムを提案し，プロトタイプシステムを用いて動 作を検証すると共に，生成された動作の質に関する評価 実験を行った。評価実験については，ワルッ，タンゴを はじめとする 7 曲について被験者 5 名の実験を行い,「リ ズム感と盛り上がり度に関しては音楽に応じた動作が生 成できている」ことが確認できたが，芸術性に関しては， まだ不十分であることも分かった。

今後はこの芸術性を高める点に焦点をあてて, さらに 研究を進めていく予定である。また，複数のオブジェク 卜の協調的な動作の生成についても今後試みてみたいと 考えている.

\section{謝辞}

本研究は一部, 日本学術振興会未来開拓学術研究推進事 業「インタラクションによる相乗効果を用いた感性創発世 界の構築」(プロジェクト番号：JSPS-RFTF99P01404) による支援を受けている。

\section{参考文献}

[1] M. Goto and Y. Muraoka: Real-time rhythm tracking for drumless audio signals - Chord change detection for musical decisions -; Working Notes of the IJCAI-97 Workshop on Computational Auditory Scene Analysis, pp. 135-144 (1997)

[2] M. Goto and Y. Muraoka: An audio-based real-time beat tracking system and its applications; Proceed- ings of the 1998 International Computer Music Conference, pp. 17-20 (1998)

[3] 後藤：拍節認識（ビートトラッキング）； bit 別冊 コン ピュータと音楽の世界—基礎からフロンティアまで一, pp. 100-116, 共立出版 (1998)

[4] M. Goto and Y. Muraoka: Real-time beat tracking for drumless audio signals: Chord change detection for musical decisions; Speech Communication, Vol. 27, Nos. 3-4, pp. 311-335 (1999)

[5] 村田, 山内, 土井：音楽を用いた対話的 3 次元 CG ア ニメーションーミュージックドリブン $\mathrm{CG}$ の試作一; 情 報処理学会ヒューマンインタフェース研究会, No. 74, pp. 1-6 (1997)

[6] J. T. Ngo and J. Marks: Physically realistic motion synthesis in animation; Evolutionary Computation, Vol. 1, No. 3, pp. 235-268 (1993)

[7] 中島:MIDIバイブル I, リットーミュージック出版 (1997)

[8] 大浜：MIDI 検定 3 級公式ガイドブック, 音楽電子事業 協会（AMEI）発行（1998）

[9] J. Kawabata, N. Saiwaki and S. Nishida: Cooperative performance system based on agents; Proceedings of 6th IEEE International Workshop on Robot and Human Communication (ROMAN'97), pp. 454-459 (1997)

[10] 才脇, 川端, 西田：心理的ポテンシャルを用いた感性協 調型合奏システム;ヒューマンインタフェース学会論文 誌, Vol. 2, No. 1, pp. 47-57 (2000)

[11] M. Carignan, Y. Yang, N. Thalmann and D. Thalmann: Dressing animated synthetic actors with complex deformable clothes; Proceedings of SIGGRAPH'92 on Computer Graphics, Vol. 26, No. 2, pp. 99-104 (1992)

[12] A. Fukunaga, J. Marks and J. T. Ngo: Automatic control of physically realistic animated figures using evolutionary programming; Proceedings of the Third Annual Conference on Evolutionary Programming (EP94), pp. 76-83 (1994)

[13] 王，才脇，西田：3D バネモデルに基づく音楽に応じた 動作生成の一手法; 第 43 回システム制御情報学会研究 発表講演会講演論文集, pp. 463-464（1999）

[14] J. Christensen, J. Marks and J. T. Ngo: Automatic motion synthesis for 3D mass-spring models; The Visual Computer, Vol. 13, Issue 1, pp. 20-28 (1997)

[15] V. J. Bolivar, A. J. Cohen and J. C. Fentress: Semantic and formal congrauncy in music and motion pictures - Effects on the interpretation of visual action; Psychomusicology, Vol. 13, pp. 28-59 (1994)

[16] S. D. Lipscomb and R. A. Kendall: Perceptual judgement of the relationship between musical and visual components in film; Psychomusicology, Vol. 13, pp. 60-98 (1994)

[17] 谷口: 音は心の中で音楽になる-音楽心理学への招待, 北 大路書房, ISBN4-7628-2173-X (2000)

[18] 岩宮：オーディオ・ビジュアル・メディアを通しての情 報伝達における資格と聴覚の相互作用に及ぼす音と映像 
の調和の影響 ; 日本音響学会誌, Vol. 48, pp. 649-657

(1992)

[19] 大串:音楽の認識心理学, 誠信書房, ISBN4-414-302838 (1998)

[20] 井口：感性情報処理，オーム社（1994） 